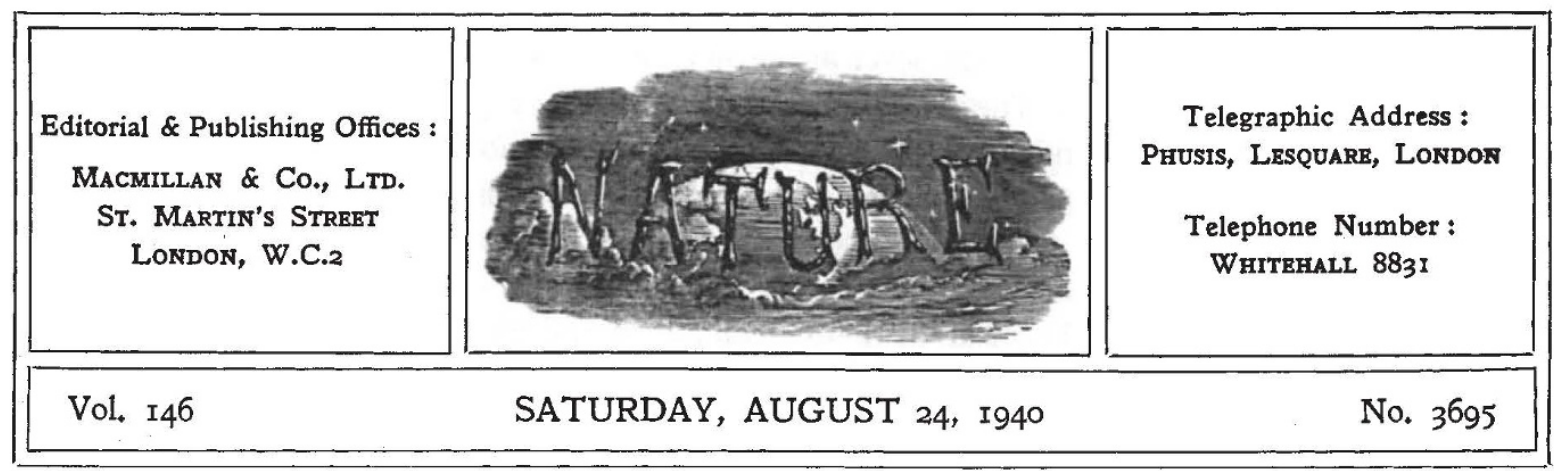

\title{
FOOD POLICY AND EUROPEAN RECONSTRUCTION
}

$T^{N}$ the rude awakening which has come to public I opinion in Great Britain and indeed elsewhere since the spring of this year, it is significant that the intensification of our national effort in the prosecution of the War has not eclipsed consideration of the problems which will confront us after the War in the task of reconstruction, whether in Great Britain or in the rest of Europe. In part it may be true that we are compelled to offer an alternative to the serf plan of European reorganization which Hitler offers. We cannot allow his plan to unite Europe to be propagated abroad without at least the broad outlines of a juster scheme which free men and nations could prepare.

The constructive and creative thought lying behind propaganda of this type is indeed a part of the war effort, to which it could well be argued. that the Ministry of Information or the British Council might devote more attention and energy. The livelier and keener attention which is now being given to this question and the major problems it presents, as compared with the more academic debates of last autumn are not, however, primarily due to questions of propaganda or prestige. Fundamentally, they are due to the growing realization that the social and economic orders are changing and will demand a new type of society after the War if stability and security are to be achieved.

The mingling of the streams of social and international policy has thus forced us to consider reconstruction and the rebuilding of world order as part of the higher policy directing our war effort. It is indeed fortunate, as we have many times insisted, that much of the planning demanded primarily for war purposes frequently lends itself admirably to planning for reconstruction.
Prof. E. H. Carr remarks in "The Twenty Years Crisis" that ultimately the best hope of progress towards international conciliation seems to lie along the path of economic reconstruction. The same view that economic reconstruction to make it impossible for Europe again to be afflicted with economic distress like that of $1929-33$ is a peace aim of the first importance has been repeatedly reiterated during the last twelve months. It is a main theme of Mr. J. E. Meade's admirable study "The Economic Basis of a Durable Peace" (London: George Allen and Unwin, Ltd., 1940. $6 s$. net.), in which he outlines a basis upon which a just and efficient system of international economic relations would be built.

A feature of the scheme is its endeavour to raise the general standard of living so far as possible and reduce inequality between nations and between classes. This would be done partly by the device recommended by the Bruce Committee and the editors of Planning of raising revenue to be spent in developing the more backward regions; in enabling the Balkans, for example, to take full advantage of the technical knowledge, the experience and the superior credit of more prosperous States. The importance of this task to the rest of the world is well brought out by Mr. F. L. McDougall, the Australian representative on the Imperial Economic Committee, in a valuable pamphlet "Food and Welfare" (Geneva Studies, vol. 9, No. 5, November 1938. Geneva Research Centre). In that area of Eastern Europe the economy depends almost entirely on primary products and material civilization has been retarded by their unhappy history.

A European development fund administered in that area with no after-thoughts, with no purpose 
except that of the improvement, economic and political, of those populations, would help to solve poverty throughout Europe in raising the level of life among the poorest peoples. These peasant populations, it should be remembered, provide almost virgin markets for industrial products. While the local consumption of protective foods must be increased in these peasant districts if a satisfactory level of health is to be ensured, these areas could still meet a large part of the demand for increased supplies of dairy products, eggs, fruit and vegetables for industrial Europe which national nutrition policies would postulate.

If, therefore, the war exigencies lead us to envisage and pursue an adequate policy of nutrition as part of our food policy, the development of that policy of nutrition in the very forefront of our economic policy on the lines recommended by the Bruce Committee should follow as a matter of course after the War. The placing by the industrial nations of improved levels of nutrition and rising standards of living in the forefront of their economic policies would create large new demands for food and raw materials. Besides stimulating their own agricultural production, especially of liquid milk, vegetables and the other more perishable forms of the protective foods, this would necessitate large increased imports of energy foods, animal feeding stuffs and the less perishable protective elements. Thus imports would be paid for by increased exports to the predominantly agricultural countries, with the result of markedly increasing world trade.

The profound disturbance to food production and distribution in Europe caused by the German occupation of Denmark, Holland, France and other countries in no way invalidates this conclusion that all nations feel the benefit of advances in nutritional policy, and it is against this background and in this prospective that we must assess proposals at present being put forward regarding the relaxation of the blockade or the storage of foodstuffs against famine. The appeals to the well-known philanthropy of the American people to break the blockade clearly derive their inspiration from enemy sources. The legal and moral issues at stake have been admirably summarized by Prof. A. L. Goodhart, an American who is professor of jurisprudence at Oxford in a letter in The Times of August 8. The distress which is already being felt in the countries occupied by Germany is largely the result of the deliberate policy of the German Government which has exploited these territories by denuding them of everything that could be added to German reserves or serve the purposes of German industry. The recent assertions from Germany that her food situation is absolutely secure further invalidates the claim that Germany should be relieved of responsibility for the feeding of those she has conquered and plundered.

The situation in Europe to-day presents no parallel or analogy with that of occupied Belgium in the War of 1914-18 when supplies were sent into occupied Belgium for distribution to the civilian population under neutral control. To-day no neutral control could be devised which would afford the slightest guarantee against abuse of any philanthropic enterprise. Any supplies reaching Nazi-occupied Europe are a direct or indirect asset to Germany and would be used without scruple for her own purposes.

If, therefore, any relaxation of the blockade of any country under German domination is unthinkable, reaffirmation of the integrity of the blockade might well be accompanied by an assurance of immediate relief as soon as that domination is removed. It is the constant purpose of Great Britain and should be a first concern of the Ministry of Information to strengthen the spirit of independence in the occupied countries, to encourage their will to resist and engender a consciousness of comradeship with those outside who are carrying on the struggle.

These are among the reasons which give fresh pertinence to the planning of a definite policy for the relief of Europe as soon as the downfall of Nazism is achieved. Such a policy would involve the co-operation of the United States and of other overseas countries, including the British Empire, some of whom have already displayed a special interest in nutrition problems.

If the situation is to be met, planning on scientific lines is essential. Much indeed of the basic knowledge is already available through the inquiries set on foot by the Bruce Committee. In the building up of large stores of surplus foodstuffs ready to be shipped into Europe as soon as Nazi domination comes to an end, as suggested by Colonel Meinertzhagen, we must take account not only of surpluses accumulating in the Americas but in Africa also. As Dr. Julian Huxley points out in a recent issue of The Times, if may be necessary to buy up surplus products, not only of human foodstuffs but also of animal foodstuffs 
and other raw materials, if the entire economy of certain large tropical regions is not to collapse. Some surpluses, such as vegetable oils, require processing, involving in turn the purchase of suitable machinery from countries whose industry is not overtaxed by armaments production and this, like the provision of storage facilities, should form part of a comprehensive plan.

Dr. Huxley's proposals indeed merit close and immediate attention. To draw up such a programme now is not only an elementary measure of foresight. It would also demonstrate that democracy can plan for the needs of peace as decisively as a dictatorship, and without sacrificing the essentials of freedom. It is the most effective answer to the pretence that British policy is bringing starvation to Europe. It is not enough to point out that it. is Nazi Germany which is starving Europe. Active preparation to feed Europe as soon as the present tyranny is overthrown is the first step to the establishment of a new European order enshrining the ideals for which Great Britain and those with her contend.

The supreme need behind such a plan is for enough public spirit and enlightenment to break through prejudices and inhibitions and act with courage and imagination. Alike in the prosecution of the struggle to which we are committed, and the building of a juster and more tolerable social order when victory has been achieved, there must be no weakness in the face of vested interests or conservative prejudice.

\section{HENRY BESSEMER AND SIDNEY GILCHRIST THOMAS}

\section{Sidney Gilchrist Thomas}

An Invention and its Consequences. By Lilian Gilchrist Thompson. Pp. $328+8$ plates. (London : Faber and Faber, Ltd., 1940.) 12s. $6 d$. net.

$\mathrm{I}^{\mathrm{N}}$ 1856, an Englishman who had recently invented a rotating projectile was witnessing guntrials with it on a French artillery practice ground near Paris. At that time, both gun and projectile were made of cast iron. These trials were a failure because of the frequency with which the gun burst, and the French commandant, who was in charge, said to him : "This invention of yours will require a better gun than one made of cast iron." So Henry Bessemer, for it was he, returned to England to make a gun tube that would not burst on firing.

$\mathrm{He}$ set to work at a foundry in St. Pancras, and after a few experiments conceived the idea of removing the impurities from molten cast iron without external heat, by blowing air through it and oxidizing them. He was a man of considerable financial resources, and in less than a month had carried out his experiments successfully. He constructed a 'converter', which was simply a pearshaped iron shell with a fireclay refractory lining fitted with tuyeres through which the air was blown. The only difficulty he had in conducting the first experiment was with his assistant, who thought he was quite mad. However, he succeeded in making him pour the melted iron from the cupola into the converter and started to blow air through it. Neither of them knew what would happen and at first nothing did happen; the reaction started quietly but then became very violent, and nearly set the place on fire. When it had finished, the converter was rotated downwards and the liquid metal poured out into a mould. In this way, he obtained an ingot of what he regarded as malleable iron. Malleable it certainly was, as numerous experiments showed. The product is what is to-day called 'mild' or 'soft' steel. He had within half an hour raised the temperature of a mass of fluid pig iron several hundred degrees, removing the greater part of the impurities without the use of any fuel, and produced a steel which was not brittle. This experiment inaugurated the era of cheap and plentiful steel.

But, to use a modern expression, Bessemer had 'got away with it' rather too easily. Quite by chance, he had used one of the few suitable brands of low-phosphorus pig iron made in Great Britain, and that is why his first experiment was successful. At that time, there was no such thing as the chemical control of the composition of cast iron. Various iron-makers set to work to repeat this process, using their own brands of cast iron, not knowing that what was right for the refinery or puddling-furnace was wrong for converters lined with siliceous materials. Almost without exception the irons produced were worthless since they were quite brittle. This brought about a complete reaction against the process which was denounced as the dream of a wild enthusiast, such as no sensible man could for a moment have entertained,

In those days there was no Iron and Steel Institute, and Bessemer had to try to solve his difficulties himself. He established the fact that it was the phosphorus in the cast iron, which was 